\title{
SARN en die natuurwetenskaplike
}

Sedert die totstandkoming van die Suid-Afrikaanse Raad vir Natuurwetenskaplikes (SARN) in 1982 het daar ingrypende veranderinge in die regering se beleid oor deregulering in Suid-Afrika gekom. Die vraag kan dus gevra word of dit nog 'n geregverdigde oogmerk is om vir die natuurwetenskaplikes 'n statutêre professionele bedeling uit te bou soortgelyk aan dié van ander wetlik erkende professies in die land. Enkele opmerkinge behoort beter begrip te bring vir die SARN se standpunt dat dit steeds in die beste belang van die Suid-Afrikaanse gemeenskap is dat die natuurwetenskaplike se professie met oordeel uitgebou behoort te word.

Die SARN, met sy funksies van registrasie, erkenning van toepaslike kwalifikasies en ervaring, en die uitoefening van dissipline, is slegs die instrument van die owerheid waarmee 'n ruimte geskep word waarbinne 'n statutêre professie kan ontstaan en ontwikkel. Die gemeenskaplikheid ten opsigte van statutêre bevoegdhede en aanspreeklikheid en verantwoordelikheid teenoor die publiek, wat uit registrasie as natuurwetenskaplike voortvloei, vorm as't ware die bindmiddels wat lede in 'n professie saamsnoer en wat gewoonlik daartoe lei dat so 'n professie dan 'n eie, belangebevorderende vereniging daarstel. Die onus rus nou op die geregistreerde natuurwetenskaplikes om ook soos ander professies buite om die SARN self daartoe oor te gaan om, binne bepaalde etiese grense, hulle eie belange te bevorder. Dit sou onbehoorlik vir SARN wees om dié terrein te betree, en sou sy geloofwaardigheid en objektiwiteit by die publiek en die owerheid ernstig in gedrang bring. Die SARN merk op dat daar by 'n beduidende aantal natuurwetenskaplikes die idee bestaan dat SARN die primêre verantwoordelikheid het om die professie daadwerklik uit te bou. Dit is ' $n$ wanbegrip.

In 'n onlangse wetswysiging het die voorbehoud op die gebruik van die benaming "Natuurwetenskaplike" deur slegs geregistreerde natuurwetenskaplikes verval. Intussen is daar nog geen werksterreine vir natuurwetenskaplikes voorbehou nie, hoewel dit volgens die wet moontlik is. Indiwiduele vakverenigings en die SARN self ondersoek tans die moontlikheid en wenslikheid van sulke voorbehoude. Dit is egter belangrik dat die publiek nou daarvan kennis behoort te neem dat die SARN daarvoor instaan dat geregistreerde natuur:vetenskaplikes oor bepaalde bevoegdhede in terme van hulle opleiding en ervaring beskik om daardie soort dienste aan die gemeenskap te lewer wat ter wille van die veiligheid en/of gesondheid of algemene belang deur 'n paslik opgeleide natuurwetenskaplike gelewer behoort te word. Verdere waarborg vir die publiek is dat die SARN wetlik bevoeg is en ook onderneem om lede van die professie te dissiplineer, sou hulle in die uitoefening van hulle professie oneties optree.

Dit kan voorsien word dat die groter kompleksiteit waarop ons beskawing onafwendbaar afstuur, groter ruimte laat vir nuwe tegnologieë, wat natuurlik gepaard gaan met 'n groter vraag na en 'n groter rol vir wetenskaplikes. En hoewel deregulering aan die orde van die dag is, vrywaar dit ons nie daarvan dat die publiek toenemend aangewese sal wees op dienste deur bevoegde wetenskaplikes nie. In dié verband kan sulke voorbeelde genoem word soos die ekologiese problematiek (met sy rob-probleem en al), die riskantheid verbonde aan die gebruik van effektiewe maar gevaarlike middels (bv. radio-isotope en onkruiddoders) en die publiek se behoefte aan geloofwaardige potensiaalbepalings ten opsigte van ontginbare minerale - almal voorbeelde van terreine waar die man op straat nie noodwendig self kan oordeel oor die bevoegdheid van 'n persoon om ' $n$ bepaalde diens aan hom te lewer nie.

Die onus rus op owerheidsinstansies, groot maatskappye, plaaslike owerhede en die publiek self om daarop aan te dring dat geregistreerde natuurwetenskaplikes met 'n gesertifiseerde bevoegdheid en wat aan 'n bepaalde etiese kode gebonde is, dienste aan die publiek sal lewer wat 'n bepaalde soort wetenskaplike kundigheid en aanspreeklikheid verg. Hiermee word hoegenaamd nie geïmpliseer dat enige diens wat maar net 'n wetenskaplike kleur het vir natuurwetenskaplikes voorbehou moet word nie. Ewe-eens is dit nou dringend nodig om die wet so te verander dat dit ook voorsiening maak dat tegnici en tegnoloë ook in die professie geakkommodeer word vanweë hulle toereikende opleiding om bepaalde dienste aan die gemeenskap te lewer (daar is reeds ver gevorder met sodanige aanpassing van die wet).

Kortliks dus: die gemeenskap moet kennis neem van die feit dat die SARN reeds 'n groot aantal (omtrent 4 000) natuurwetenskaplikes geregistreer het en instaan vir hulle bevoegdheid om wetenskaplike dienste binne bepaalde etiese norme aan die gemeenskap te lewer. Terselfdertyd is daar 'n dringende behoefte daaraan dat geregistreerde natuurwetenskaplikes deur hulle vakverenigings nou self hulle professie daadwerklik sal uitbou.

H.S. HOFMEYR 